\begin{tabular}{|c|c|c|}
\hline JURNAL & ISSN: 2502-6496 (Print) \\
\hline $\begin{array}{c}\text { Volume 1, Nomor 2, p 45 - 51 } \\
\text { Oktober 2017 }\end{array}$ & http://zona.pelantarpress.co.id/ \\
\hline
\end{tabular}

\title{
Analisis pencemaran antropogenik dan struktur komunitas diatom planktonik sebagai indikator pencemaran perairan di Selat Air Hitam
}

\author{
Miduk Tampubolon ${ }^{1}$, Yusni Ikhwan Siregar ${ }^{2}$, Sofyan Husein Siregar ${ }^{2}$ \\ ${ }^{1}$ Komisaris CV Menara Struktur Andalas. \\ ${ }^{2}$ Dosen Pascasarjana Ilmu Lingkungan Program Pascasarjana Universitas Riau.
}

\begin{abstract}
The present study aimed at identify population characters pollution source which affect water fertily nitrate, phospate, abundance as well as community structure of planctonic diatomae were measured. Nine sampling station of three location were established a long the Selat Air Hitam water. Appearently domestic activity, marine traffic, sago processing plant and community economic had affected on water fertility due to effluent water that entered the water. Nitrate analysis showed a range of 187,5 to 262,5 $\mu \mathrm{g} / \mathrm{L}$ mean while phospate consentration appear 28,8-241,2 $\mu \mathrm{g} / \mathrm{L}$, silicate consentration appear 30,4-32,9 $\mu \mathrm{g} / \mathrm{L}$. Plactonic diatomae abundance came up 2400 to $3800 \mathrm{cell} / \mathrm{L}$ of nine genera. Biodiversity index of range $\left(1 \leq H^{\prime} \leq 3\right)$, while smiliarity index $(0,5 \leq E \leq 1)$ and dominancy index $(0,5 \leq E \leq 1)$. Those index indicate nthe Selat Air Hitam waters in a medium pressure, however ecosystem condition is stable. Nitrate, phospate and silicate positively and significantly correlated with diatomae abundance $(p<0,05)$. TSS level appeared 18,33 - 45,00 mg/l and BOD berkisar 3,73 - 5,07 mg/l. Regression analysis showed that nitrate and phospate had a mayor affect to diatomae abundance.
\end{abstract}

Keywords: Diatoms, Pollution, Selat Air Hitam

Pembangunan berkelanjutan menjadi tonggak pembangunan daerah saat ini sehingga penting untuk memperhatikan aktivitas pembangunan dan keseharian masyarakat. Kualitas perairan terutama tingkat kesuburannya dipengaruhi oleh adanya aktivitas domestik penduduk di wilayah pesisir. Kondisi pengelolaan lingkungan di wilayah pesisir tetap saja terlihat bahwa akhir dari limbah aktivitas domestik dan industri bermuara ke perairan. Aktivitas tersebut menambah konsentrasi zat-zat tertentu di perairan.

Letak perairan Selat Air Hitam yang berada diantara dua pulau besar sehingga aktivitas di kedua pulau tersebut berpotensi mempengaruhi kesuburan perairan, baik aktivitas di wilayah daratan maupun di perairan itu sendiri. Konsentrasi zat hara perairan serta tingkat kesuburan perairan tidak lagi berlangsung secara alami akan tetapi telah dipengaruhi oleh adanya aktivitas di wilayah pesisir. Kondisi demikian dapat berdampak pada terjadinya pencemaran di perairan yang berpengaruh terhadap tingkat kesuburan suatu perairan. Struktur komunitas diatom planktonik suatu perairan dan faktor-faktor yang mempengaruhi tingkat kelimpahannya sangat penting untuk diketahui terkait tingkat kesuburan perairan.

\section{METODE PENELITIAN}

Penelitian ini dilaksanakan di wilayah perairan Selat Air Hitam Kabupaten Kepulauan Meranti dari Oktober - Desember 2014. Pengambilan sampel dilakukan di 3 stasiun pengamatan (Gambar 1 dan Tabel 1). Parameter perairan yang diambil meliputi parameter biologi (diatom), fisika (suhu, salinitas, kecerahan, kecepatan arus) dan parameter kimia ( $\mathrm{pH}$, oksigen terlaut, TSS, BOD, nitrat, phospat, silikat). Pengambilan contoh diatom dilakukan menggunakan plankton net yang berbentuk kerucut dengan mata jaring $25 \mu \mathrm{m}$. Contoh diatom yang diperoleh masing-masing disimpan dalam botol contoh dan diberi larutan pengawet lugol 1\%. Contoh diatom ini diidentifikasi di Laboratorium Ekologi Perairan Fakultas Perikanan dan Ilmu Kelautan Universitas Riau.

Pengukuran parameter fisika dilakukan secara insitu meliputi suhu diukur menggunakan termometer dan salinitas diukur menggunakan hand held refractometer, kecerahan diukur menggunakan secchi disc, kecepatan arus diukur menggunakan current meter. Pengukuran parameter kimia, yaitu $\mathrm{pH}$ menggunakan $\mathrm{pH}$ meter, oksigen terlarut menggunakan DO meter. Contoh air untuk penentuan konsentrasi unsur hara (nitrat, phospat, silikat) dan parameter kimia (TSS, BOD) diambil menggunakan water sampler. Analisis unsur hara dilakukan di Laboratorium Kimia Laut Fakultas Perikanan dan Ilmu Kelautan Universitas Riau sedangkan analisis TSS dan BOD dilakukan di Laboratorium Ekologi Perairan. Peralatan pendukung lainnya yang dipergunakan yaitu GPSmap Garmin 62s, kamera digital, peralatan tulis, kertas label, isolatif, cutter, buku catatan dan lain-lain. Metode penelitian yang digunakan adalah metode deskripsi dengan menyajikan hasil pengamatan dalam bentuk tabel dan grafik dan kemudian dianalisis secara deskriptif. 


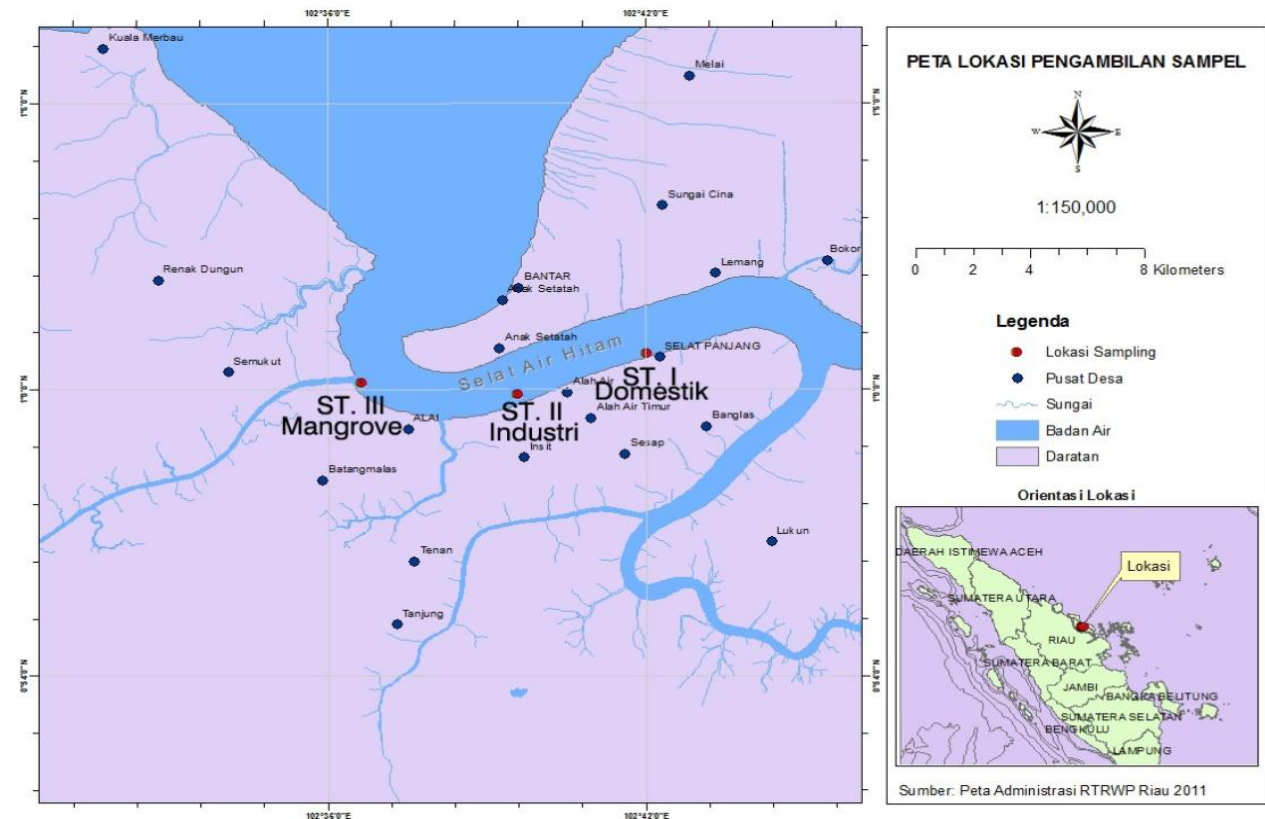

Gambar 1. Lokasi penelitian di perairan Selat Air Hitam Kepulauan Meranti

\section{HASIL DAN PEMBAHASAN}

\section{Kondisi Umum Wilayah}

Secara geografis perairan Selat Air Hitam diapit oleh Pulau Rangsang dan Pulau Tebing Tinggi Kabupaten Kepulauan Meranti. Parameter lingkungan yang diukur dalam penelitian ini dan disajikan dalam nilai rata-rata dapat menunjukkan kondisi wilayah perairan Selat Air Hitam sebagaimana ditampilkan pada Tabel 2.

Tabel 2. Parameter lingkungan perairan Selat Air Hitam Kepulauan Meranti

\begin{tabular}{lccc}
\hline Parameter & St. 1 & St. 2 & St. 3 \\
\hline - Suhu $\left({ }^{\circ} \mathrm{C}\right)$ & 31,0 & 30,5 & 30,3 \\
- Ph & 6,7 & 6,0 & 6,0 \\
- Salinitas (\%) & 21,3 & 20,7 & 21,7 \\
- Kecerahan (cm) & 65,0 & 38,3 & 28,3 \\
- Kecepatan Arus (m/det) & 0,1 & 0,4 & 0,2 \\
- Oksigen Terlarut (mg/l) & 6,1 & 6,6 & 7,0 \\
- TSS (mg/l) & 18,3 & 28,7 & 45,0 \\
- BOD (mg/l) & 3,7 & 5,1 & 4,1 \\
\hline
\end{tabular}

Sumber: Data Primer

\section{Karakterisrik Aktivitas Masyarakat Bantaran Selat Air Hitam.}

\section{Aktivitas permukiman nelayan}

Permukiman padat penduduk di bantaran Selat Air Hitam berpotensi menghasilkan limbah cair yang yang diperkirakan sama besar jumlahnya dengan kebutuhan air bersih penduduk (70 liter/orang/hari). Limbah cair ini berasal dari air buangan kakus (black water) dan air mandi, cuci serta aktivitas dapur (grey water). Limbah padat berupa sampah domestik aktivitas rumah tangga diperkirakan sebesar $2,5 \mathrm{~kg} /$ orang/hari. Dengan kondisi ini maka pada perkiraan jumlah limbah aktivitas masyarakat di kedua pulau yang mengapit perairan Selat Air Hitam ditampilkan pada Tabel 3.

Tabel 3. Perkiraan produksi sampah dan limbah cair dari aktivitas rumah tangga

\begin{tabular}{ccc}
\hline Deskripsi & Pulau Rangsang & Pulau Tebing Tinggi \\
\hline Penduduk (jiwa) & 53.357 & 84.736 \\
Nelayan (RTP) & 2.469 & 639 \\
Timbulan Sampah (ton/hari) & 133,4 & 211,8 \\
Limbah Black Water $\left(\mathrm{m}^{3} /\right.$ hari) & 747,0 & $1.186,3$ \\
Limbah Grey Water $\left(\mathrm{m}^{3} /\right.$ hari) & $2.988,0$ & $4.745,3$ \\
\hline
\end{tabular}


Kondisi kehidupan masyarakat nelayan di bantaran Selat Air diperkirakan menghasilkan sampah sebesar 345,2 ton/hari dan limbah cair berupa air kotor domestik grey water $7.733,2 \mathrm{~m}^{3} /$ hari dan black water $1.933,3 \mathrm{~m}^{3} /$ hari. Sementara aktivitas lainya yang berpotensi menghasilkan sampah dan limbah adalah aktivitas usaha perekonomian masyarakat. Menurut Asis (dalam Nurmayanti, 2002) kondisi ini telah menyumbangkan limbah ke perairan dari aktivitas domestik penduduk.

\section{Aktivitas lalu lintas kapal}

Selat Air Hitam secara hidrologis merupakan perairan semi tertutup dimana arus pasang surut mendominasi pergerakan arus air laut. Kesibukan utama sebagai jalur transportasi kapal penumpang dan barang yang masuk dan keluar dari/ke Kota Selat Panjang. Selain itu, perairan ini juga menjadi daerah penangkapan ikan bagi nelayan setempat sehingga menambah kesibukan transportasi perahu motor yang berlalu lalang setiap harinya. Potensi limbah yang dihasilkan dari kapal penumpang, barang dan perahu nelayan diantaranya air ballast kapal, cecera minyak pada ruang mesin, sampah makanan, dan sampah dari material yang diangkut oleh kapal barang. Jumlah kapal yang berlalu lalang di perairan ini sebagaimana pada Tabel 4.

Masuknya limbah ke dalam perairan akan mempengaruhi sifat-sifat biologis dari perairan tersebut (Marwan dalam Silitonga, 2014). Lalu lintas kapal penumpang, barang dan kapal nelayan potensial membuang limbah ke perairan melalui air buangan yang mengandung oli kotor dan ceceran minyak dari mesin kapal. Adanya aktivitas di atas kapal juga menghasilkan sampah seperti sisa makanan dan juga sampah-sampah material barang angkutan maupun sisa umpan nelayan.

\section{Aktivitas industri pengolahan sagu}

Kepulauan Meranti telah dikenal sebagai daerah penghasil sagu. Produksi sagu di wilayah ini didukung oleh luas area tanam dan produksi. Di Pulau Rangsang, luas area tanam sagu sebesar 2.878 ha dengan produksi 18.378 ton/tahun. Pulau Tebing Tinggi memiliki luas area tanam sagu sebesar 25.806 ha dengan produksi 135.585 ton/tahun. Industri hulu pengolahan sagu di daerah ini menghasilkan tepung sagu sementara industri hilir menghasil produk berupa mie sagu. Limbah industri pengolahan sagu berasal dari proses penyaringan bubur empelur sagu (ekstraksi) dan pengendapan pati. Pati sagu yang dihasilkan dari proses ekstraksi empelur batang sagu $<20 \%$ sedangkan limbah produksi yang dihasilkan $>80 \%$ berupa kulit batang, ampas sagu, dan air pencucian. Limbah yang dihasilkan dari proses pembuatan mie sagu utamanya adalah air yang digunakan dalam proses produksi.

Umumnya unit pengolahan sagu milik masyarakat di bantaran perairan Selat Air Hitam berada di tepi aliran pasang surut (tidal creek) sehingga cenderung membuang limbah hasil pencucian sagu ke perairan. Jumlah industri pengolahan sagu di wilayah ini ditampilkan pada Tabel 5.

Tabel 5. Jumlah industri hulu dan hilir pengolahan sagu di Kepulauan Meranti

\begin{tabular}{ccccc}
\hline \multirow{2}{*}{ No } & \multirow{2}{*}{ Jenis Industri } & \multirow{2}{*}{ Jumlah (unit) } & \multicolumn{2}{c}{ Kapasitas Produksi (ton/hari/unit) } \\
\cline { 3 - 5 } & & 67 & Produk & Limbah \\
\hline 1. & Industri pengolahan sagu & $6,6-1,8$ & $3-9$ \\
2. & Industri pengolahan mie sagu & $>25$ & $0,05-0,1$ & $0,25-0,5$ \\
\hline
\end{tabular}

Sumber: Disperindagkop \& UMKM Kep. Meranti, 2014

Air limbah pencucian sagu dapat meningkatkan kekeruhan perairan (Haryanto dan Siswari, 2004), mengandung karbon yang sangat tinggi untuk rasio nitrogen (Phang et. al., 2000), mengandung nilai COD yang cukup tinggi (Pei-Lang et. al., 2006) dan menyebabkan reaksi browning pada air limbah hasil ekstraksi (Onsa et. al. dalam Konuma et. al., 2013).

\footnotetext{
Aktivitas usaha ekonomi masyarakat

Aktivitas usaha perekonomian masyarakat di bantaran Selat Air Hitam yang meliputi toko, warung kelontong, rumah makan, restoran, swalayan, supermarket, hotel, penginapan dan pasar, umumnya menghasilkan sampah organik ataupun anorganik. Sistem pengelolaan terhadap persampahan yang tidak tertata dengan baik, maka sampah yang dihasilkan dari aktivitas tersebut pada akhirnya terbuang ke perairan. Jenis dan jumlah usaha perekonomian masyarakat ditampilkan pada Tabel 6 .
} 
Tabel 6. Jumlah usaha perekonomian masyarakat di Pulau Tebing Rangsang dan Tebing Tinggi Kepulauan Meranti

\begin{tabular}{ccc}
\hline No. & Usaha Perekonomian & Jumlah (unit) \\
\hline 1. & Toko/Warung Kelontong & 1.375 \\
2. & Rumah Makan/Restoran & 418 \\
3. & Swalayan/Supermarket & 233 \\
4. & Hotel/Penginapan & 12 \\
5. & Pasar & 7 \\
\hline
\end{tabular}

Sumber: Kepulauan Meranti Dalam Angka, 2014

\section{Konsentrasi Nitrat, Phospat dan Silikat}

Konsentrasi unsur hara nitrat di perairan Selat Air Hitam berkisar 187,5 - 262,5 $\mu \mathrm{g} / 1$. Konsentrasi phospat berkisar 28,8 - 241,2 $\mu \mathrm{g} / 1$. Konsentrasi silikat berkisar 30,4 - 32,9 $\mu \mathrm{g} / 1$. Perbandingan nilai konsentrasi rata-rata hara perairan Selat Air Hitam masing-masing stasiun diketahui silikat $<$ phospat $<$ nitrat dapat dilihat pada Gambar 2.

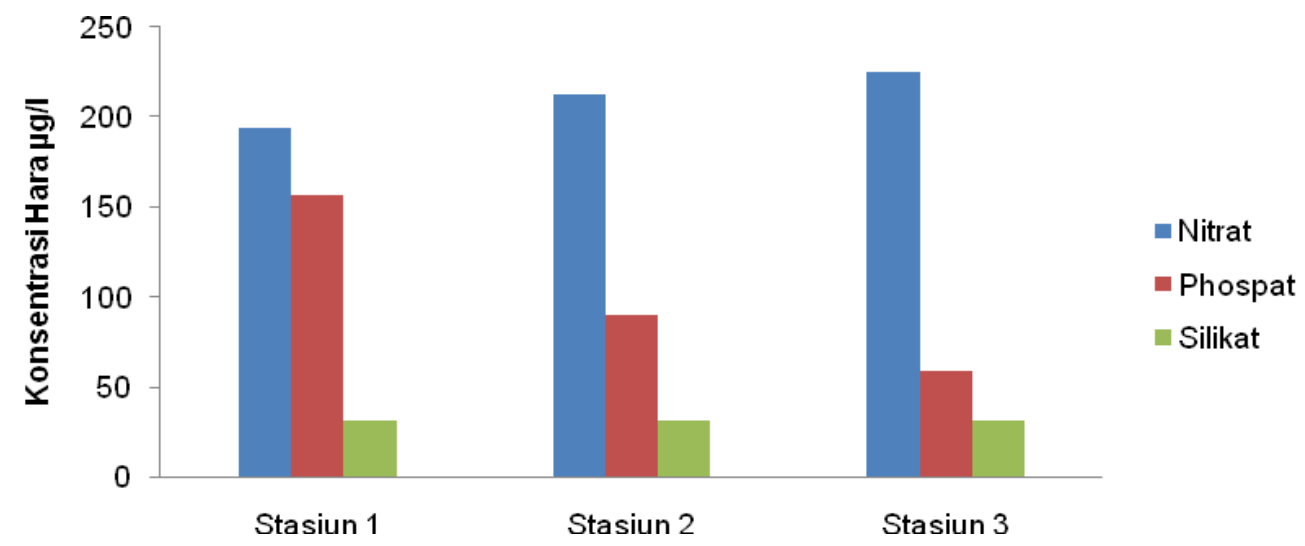

Gambar 2. Histogram konsentrasi nitrat, phospat dan silikat di perairan Selat Air Hitam

Konsentrasi nitrat tertinggi terlihat di Stasiun 3 yang merupakan kawasan mangrove. Marpaung (2013) berpendapat bahwa tingginya konsentrasi nitrat pada ekosistem mangrove disebabkan karena adanya serasah mangrove yang terkumpul pada suatu kawasan kemudian membusuk dan mengendap pada lumpur sehingga pada saat pasang naik menyebabkan serasah terurai masuk ke perairan.

Konsentrasi phospat tertinggi terlihat di Stasiun 1 yang merupakan kawasan domestik (baik permukiman maupun aktivitas usaha ekonomi). Winata et. al. (2000) menyebutkan bahwa air buangan penduduk yang menggunakan bahan detergen dan air buangan tinja serta sisa makanan mengandung poliphospat dan phospat organik.

Sementara konsentrasi silikat di stasiun pengamatan tidak begitu memiliki perbedaan yang mencolok. Menurut Fitrya (2011), rendahnya kadar silikat mungkin ada kaitannya dengan silikat digunakan untuk pertumbuhan dan perkembangan diatom.

\section{Kelimpahan Diatom Planktonik}

Kelimpahan diatom planktonik di perairan Selat Air Hitam antar stasiun berkisar 2567 - 3200 sel/L. Kelimpahan tertinggi berada pada Stasiun 2. Jenis diatom plantonik yang ditemukan terdiri dari 9 genera. Jumlah kelimpahan masing-masing ditunjukkan pada Tabel 6. 
Miduk Tampubolon et al | ZONA 1 (2) (2017) 44-51

Tabel 6. Kelimpahan diatom planktonik di perairan Selat Air Hitam

\begin{tabular}{|c|c|c|c|c|c|c|c|c|c|}
\hline \multirow[b]{2}{*}{ Genus } & \multicolumn{3}{|c|}{ Stasiun I } & \multicolumn{3}{|c|}{ Stasiun II } & \multicolumn{3}{|c|}{ Stasiun III } \\
\hline & Titik 1 & Titik 2 & $\begin{array}{c}\text { Titik } \\
3\end{array}$ & Titik 1 & Titik 2 & Titik 3 & Titik 1 & Titik 2 & $\begin{array}{c}\text { Titik } \\
3\end{array}$ \\
\hline $\begin{array}{l}\text { 1. Asterionella } \\
\mathrm{sp} .\end{array}$ & 400 & 400 & 400 & 500 & - & - & - & 400 & 800 \\
\hline $\begin{array}{c}\text { 2. Actinocyclus } \\
\text { sp. }\end{array}$ & 400 & 800 & 700 & - & 800 & 400 & - & - & 1200 \\
\hline 3. Cocconeis sp. & - & - & - & - & - & 700 & - & - & - \\
\hline 4. Diatomae sp. & 600 & - & 800 & - & - & - & 800 & - & - \\
\hline 5. Navicula sp. & - & 400 & - & 800 & - & 400 & - & - & - \\
\hline 6. Nitzschia sp. & - & 600 & 400 & 1200 & 900 & 1000 & 1200 & 1200 & 600 \\
\hline $\begin{array}{l}\text { 7. Pleurosigma } \\
\text { sp. }\end{array}$ & 600 & - & - & - & - & - & 400 & 600 & 800 \\
\hline $\begin{array}{l}\text { 8. Thalassiosira } \\
\text { sp. }\end{array}$ & 400 & 400 & 400 & 900 & 900 & 400 & 400 & - & 400 \\
\hline $\begin{array}{l}\text { 9. Triceratium } \\
\text { sp. }\end{array}$ & - & - & - & - & 400 & - & - & 800 & - \\
\hline Jumlah/sub st & 2400 & 2600 & 2700 & 3100 & 2800 & 2900 & 2800 & 3000 & 3800 \\
\hline Jumlah/stasiun & & 7700 & & & 8500 & & & 9600 & \\
\hline
\end{tabular}

Sumber: Analisis Data Gambar 3.

Komposisi diatom planktonik yang ditemukan di perairan Selat Air Hitam ditampilkan pada

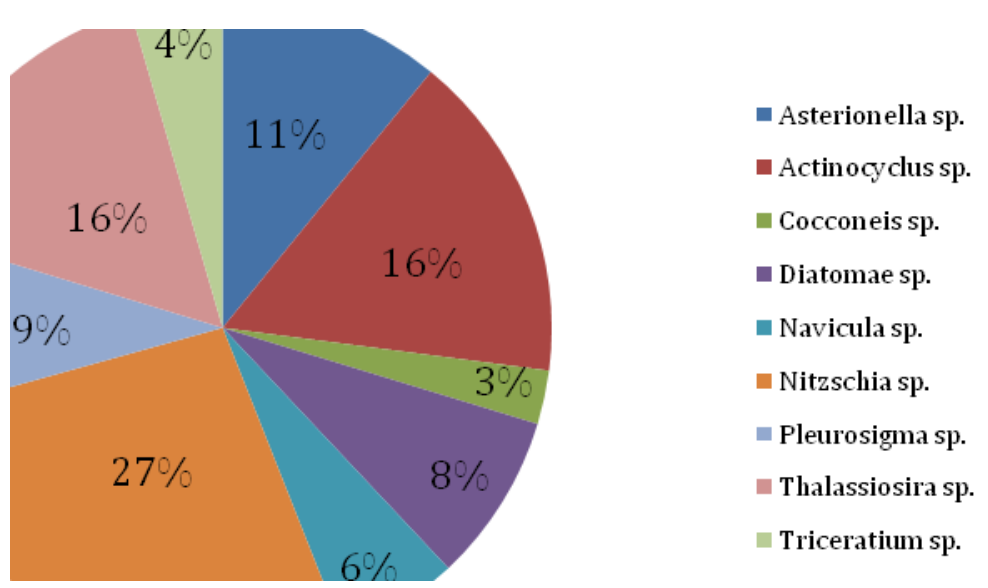

Gambar 3. Komposisi diatom planktonik perairan Selat Air Hitam

\section{Struktur Komunitas Diatom Planktonik}

Struktur komunitas terdiri dari indeks keseragaman $\left(\mathrm{H}^{\prime}\right)$, indeks keseragaman (E) dan indeks dominansi (C). Struktur komunitas diatom planktonik perairan Selat Air Hitam dapat dilihat pada Gambar 4. 


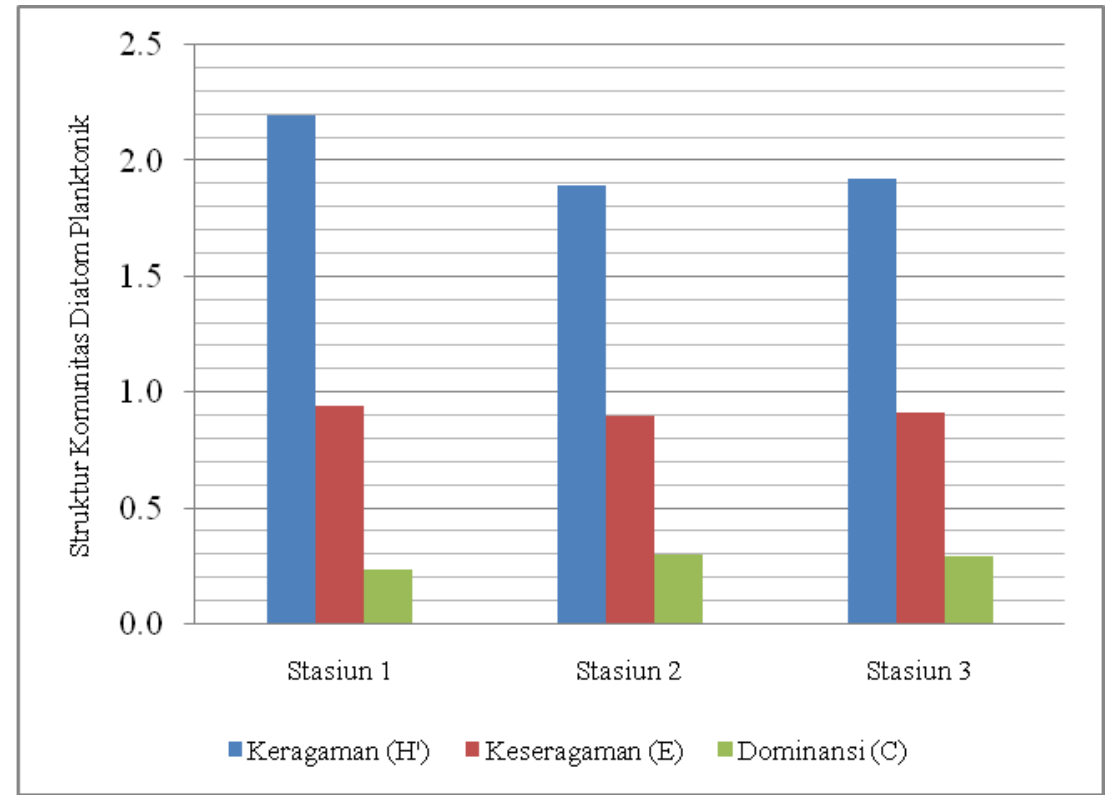

Gambar 4. Histogram struktur komunitas diatom planktonik perairan Selat Air Hitam

Indeks keragaman $\left(\mathrm{H}^{\prime}\right)$ diatom planktonik di perairan Selat Air Hitam berkisar 1,899 - 2,196. Sedangkan indeks keragaman (E) berkisar 0,904-0,946. Sementara indeks dominansi (C) berkisar 0,236 0,303 . Menurut Effendi (2003) bahwa diatom memiliki respon yang berbeda-beda terhadap kondisi perairan sehingga jenisnya bervariasi di berbagai tempat. Menurut Hasibuan (2008), distribusi diatom sangat bergantung dari penetrasi cahaya matahari ke perairan, pengaruh suhu, zat hara dan pemangsaan organisme herbivora. Kelimpahan rata-rata berkisar 2400 - $3800 \mathrm{sel} / \mathrm{L}$, kelimpahan tertinggi berada pada Stasiun 3.3 (3800 sel/L). Menurut Pakpahan (2013), bahwa perbedaan kelimpahan disebabkan oleh perbedaan pengaruh kegiatan di sekitar perairan dan kondisi pada setiap stasiun, dimana setiap lokasi memiliki pengaruh anthropogenik yang berbeda-beda dan pasokan unsur hara mempengaruhi pertumbuhan diatom di perairan. Berdasarkan kelimpahan diatom, perairan Selat Air Hitam tergolong pada perairan mesotrofik, yaitu perairan dengan tingkat kelimpahan diatom antara $2000-15000 \mathrm{sel} / \mathrm{L}$.

Indeks keragaman jenis $\left(\mathrm{H}^{\prime}\right)$ diatom menunjukkan keragaman dalam kategori kestabilan komunitas yang sedang dan perairan belum mengalami gangguan yang terlihat dari nilai indeks $1 \leq \mathrm{H}^{\prime} \leq 3$. Menurut Clark (dalam Pamungkas, 2011), keragaman spesies menunjukkan keseimbangan ekosistem, semakin tinggi keragaman spesies maka semakin seimbang ekosistem tersebut.

Indeks keseragaman (E) diatom $0,5 \leq \mathrm{E} \leq 1$ atau mendekati 1. Berdasarkan metode Pilou dalam Krebs (1989), berarti keseragaman organisme di perairan tersebut berada dalam keadaan seimbang, artinya tidak terjadi persaingan tempat tinggal maupun dalam memperoleh makanan.

Indeks dominansi (C) diatom $0 \leq C \leq 0,5$ atau mendekati 0 yang artinya tidak ada diatom yang mendominasi di perairan tersebut. Menurut Widodo (dalam Pakpahan, 2013), perubahan-perubahan dominansi jenis plankton dipengaruhi oleh faktor-faktor lingkungan seperti perubahan suhu, variasi $\mathrm{pH}$, kandungan unsur hara, penetrasi cahaya dan kondisi biologi.

\section{KESIMPULAN}

Karakteristik aktivitas masyarakat di sekitar perairan Selat Air Hitam yang teridentifikasi yaitu aktivitas domestik (permukiman), lalu lintas kapal, industri pengolahan sagu dan aktivitas usaha ekonomi masyarakat. Aktivitas masyarakat tersebut dapat berpengaruh terhadap kesuburan perairan karena telah menjadi sumber masuknya limbah ke perairan berupa sampah organik dan anorganik baik cair maupun padat. Konsentrasi unsur hara nitrat di perairan Selat Air Hitam berkisar 187,5 - 262,5 $\mu \mathrm{g} / 1$, phospat berkisar $28,8-241,2 \mu \mathrm{g} / 1$ dan silikat berkisar 30,4 - 32,9 $\mu \mathrm{g} / 1$ yang menunjukkan tingkat perbandingan konsentrasi silikat $<$ phospat $<$ nitrat. Kelimpahan diatom planktonik yang ditemukan berkisar $2400-3800$ sel/L dari 9 genera. Indeks keseragaman $\left(1 \leq \mathrm{H}^{\prime} \leq 3\right)$, indeks keseragaman $(0,5 \leq \mathrm{E} \leq 1)$ dan indeks dominansi $(0 \leq \mathrm{C} \leq 0,5)$ menunjukkan bahwa perairan telah mengalami tekanan pada tingkat sedang, tetapi kondisi masih seimbang dan tidak ada jenis yang mendominasi. 


\section{UCAPAN TERIMAKASIH}

Penulis menyampaikan terimakasih kepada seluruh pihak yang membantu dalam kelancaran penelitian ini.

\section{DAFTAR PUSTAKA}

Effendi, H. 2003. Telaah Kualitas Air Bagi Pengelolaan Sumberdaya dan Lingkungan Perairan. Kanisius, Yogyakarta.

Fitrya, N.,2011. Biodiversitas dan Kondisi Oseanografi di Kawasan Perairan Kepulauan Natuna. Laporan Akhir Ekspedisi Widya Nusantara (E-WIN). Pusat Penelitian Oseanografi - LIPI. 322 hal.

Konuma, H., R. Rolle dan S. Boronthanarat. 2013. Correlation of Browning of Starch Extracted from Sago Palm (Metroxylon sagu Robb) to the Phenolic Contens and Ecosystem Conditions of Growth. Journal of Agricultural Technology, 9 (1) : 193-200.

Krebs, C.J., 1989. Ecology Methodology. Harper and Row Inc. Publisher, New York. 654 p.

Marpaung, L. S., 2013. Struktur Komunitas Diatom Planktonik dengan Konsentrasi Nitrat dan Phospat di Muara Sei Undan Kecamatan Reteh Kabupaten Indragiri Hilir. Program Studi Ilmu Kelautan. Fakultas Perikanan dan Ilmu Kelautan. Universitas Riau, Pekanbaru.

Nurmayanti. 2002. Kontribusi Limbah Domestik terhadap Kualitas Air Kaligarang Semarang. Tesis. Program Pascasarjana Universitas Gadjah Mada, Yogyakarta. (tidak diterbitkan).

Pakpahan, L. S., 2013. Konsentrasi Nitrat dan Fosfat serta Kelimpahan Diatom di Perairan Bekas Pertambangan Timah Kelurahan Sungai Lakam Kabupaten Karimun Provinsi Kepulauan Riau. Fakultas Perikanan dan Ilmu Kelautan. Universitas Riau, Pekanbaru.

Pamungkas, N. A. 2011. Perkembangan Fitoplankton dengan Pemberian Pupuk Organik Cair. Jurnal Berkala Perikanan Terubuk. 39 (1) : 79-90.

Silitonga, B. 2014. Analisis Kandungan Bahan Organik Sedimen dan Makrozoobenthos di Perairan Selat Panjang Kabupaten Kepulauan Meranti Provinsi Riau. Program Studi Ilmu Kelautan. Fakultas Perikanan dan Ilmu Kelautan. Universitas Riau, Pekanbaru.

Winata, I. N. A, A. Siswoyo dan T. Mulyono. 2000. Perbandingan Kandungan P dan N Total dalam Air Sungai di Lingkungan Perkebunan dan Persawahan. Jurnal Ilmu Dasar, 6 (1) : 34-42. 